\title{
MONTENEGRO IN TRAVELOGUE BLACK LAMB AND GREY FALCON: A JOURNEY THROUGH YUGOSLAVIA, 1941) REBECCA WEST
}

\author{
Miluša Bakrač
}

\begin{abstract}
The subject of this paper will be the presentation of Montenegro in the travelogue Black Lamb and Grey Falcon by Rebecca West. This travelogue will be analysed from the literary-historical, literary-theoretical and imagological perspectives. We will deal with the chronotope of Montenegro (Kolashin, Podgorica, Cetinje and Budva) and the national identity of the Montenegrin people from the viewpoint of a travelogue narrator that does not belong to that nation, as well as the creation of transnational identities. We will also pay attention to the construction of ethnic stereotypes and their (non)duration in time. The paper will also include a comparison of characters and events depicted in the travelogue with historical figures and the events on which they are modelled.

"The key assumption of the literary-historical approach to the travelogue discourse is finding its typical places, shaping specific rhetoric of the travelogue based on a few backings from the narratology to the history of mentality." (Duda 1998, 92) The presentation of Montenegro in the travelogue Black Lamb and Grey Falcon will be based on Duda's assumptions and Bakhtin's perception of chronotope as "the essential interconnection of time and space relations" (Bakhtin 1989, 193). We will also take into account the views of Gerard Genette and Mieke Bal.
\end{abstract}

Keywords: identity, Montenegro, stereotype, travelogue 


\section{INTRODUCTION}

The paper will be based on literary-theoretical concepts of Mikhail Bakhtin, Gerard Genette and Mieke Bal. We will pay attention to the key theoretical concepts that will significantly contribute to adequate understanding of the subject we will analyse.

Bakhtin's interpretation of time and space relations in literary text (chronotope) and narratological theory of Gerard Genette and Mieke Bal that are related to elements of narrative text (narrator, point of view and time category) will stand out.

The term chronotope was firstly introduced in the literary science by Mikhail Bakhtin. It was used in mathematics and it was introduced and proved by Einstein's relativity theory. In the literary science this term does not have the same meaning as in the relativity theory, it has metaphorical meaning. The term chronotope expresses the unbreakable connection between time and space and it should be understood as formally-substantial category of literature. (Bakhtin 1989)

"In the literary artistic chronotope, spatial and temporal indications are fused into one carefully thought-out, concrete whole. Time, as it were, thickens, takes on flesh and becomes artistically visible; likewise, space becomes charged and responsive to the movements of time, plot and history. The intersection of axes and fusion of indicators characterizes the artistic chronotope.(...) The chronotope as a formally-substantial category determines (to a considerable extent) the character of a man in literature; this character is always essentially chronotopic.(Bakhtin 1989, 194)

Besides the term chronotope, the terminology of Gerard Genette (focalization, focalizer and analepsis) will also be used in this paper.

Gerard Genette, in his narratological theory, starts from the assumption that the semantic aspects of an individual literary work are important in every theoretical analysis. The nature of narrative text, in his opinion, should be sought in the way the story is presented. He emphasizes the voice, time and mood as the main constructive elements of each narrative text.

Most often the narrative mood ('perspective' or 'point of view') did not differ from the narrative voice; there was no difference made between 
the person whose point of view directs the narrative perspective and narrator. (Marcetic 2003)

Gerard Genette, under the concept of focalization, implies a point of view, i.e. focus of narration. The focus of narration represents a character's or narrator's fictional consciousness, through which events, situations and other elements of narration are presented.

This author makes distinction between perspective, point of view (narrative mode) and narrative voice (narrator). He makes the difference between the subject of the observation, i.e. the bearer of the point of view (focalizer) and the subject who narrates events in the text, i.e. the narrator. (Marcetic 2003)

According to relation between narrator and the story he narrates, Genette distinguishes two basic narrative situations, homodiegetic and heterodiegetic narrative. (...) Homodiegetic narrative is the story told by the narrator who is, at the same time, one of the characters in the story, and the heterodiegetic narrative is the story told by narrator who is not present as a character in the story. (...) The basic or autonomous status has the level at which the narration takes place - the narrator's level. The level of the characters and of all other secondary narrators to whom the basic narrator can give the word at some point are "subordinated" to the narrator's level. (Marcetic 2003, 85)

Mieke Bal interprets focalization as a "relation between the subject who 'sees' and the object that is 'seen' (...) Subject of focalization, focalizer, is the point of view from which the elements are observed." (Bal 2000, 123124)

The author sees the narratological text as the story expressed by language signs and she makes a clear distinction between the writer and the narrator. This should be particularly taken into consideration when we talk about travelogue because it, more than any other literary genre, lets the reader to overlook this distinction.

"As it follows from the definition of narrative text, the instance who narrates produces language signs. It is not a writer. He gives a word to the fictional speaker; technically speaking it is the instance called narrator. But the narrator does not speak all the time. In the parts of the text where the direct speech is used, it seems like the narrator temporarily gives the 
word to the character. Thus, when describing levels in the text, it is very important to determine who is speaking. (Bal 2000, 15)

Boris Uspensky dealt with problems with point of view in detail in his works Poetics of Compostions and The Semiotics of the Icon. Uspensky analyzed the point of view in ideological, phraseological and spatiotemporal sense. (Uspensky 1979)

Analysing the category of time in narrative text, Genette emphasizes that "every narration is double-temporal": narrative text "lasts" in two temporal dimensions- dimension of the story (the narrated events) and dimension of narration (narrative text itself). The time of the story is, conditionally speaking, chronological, because the events here are lined in order in which they occurred, while the time of narration, or, as the Russian formalists say, the time of topic, is subjected to different temporal distortions. (...) The term anachronies Genette uses for all different forms of chronological time deviation in the story. "(Marcetic 2003, 113) An analepsis is an achronological movement back in time, so that a chronologically earlier incident is related later in the text. Retrospective movements of the character this author calls subjective analepses, and the narrator's chronological time deviations he calls objective analepsis. (Marcetic 2003)

We will also pay attention to imagology as a part of comparative literature which studies how certain temperamental characteristics are stereotypically imputed to certain nationalities, and look methodological support on it.

The imagology is a special research branch of comparative literature that deals with the study of literary images about foreign countries and nations (hetero-image) and about their own country and nation (autoimage). (Dukic in Dukic, Blazevic, Plejic Poje, Brkovic 2009, 5)

In the basis of imagology there is creating an image of the "other". "Image is the description of a foreign cultural reality by which an individual or group that have shaped it (...) reveal and interpret the cultural and ideological space in which they are located. (Pageaux in Dukic, Blazevic, Plejic Poje, Brkovic 2009)

In the travelogue Black Lamb and Grey Falcon the travelogue subject constructs the image of Other based on the title syntagm which is 
the antithetic pair of victim and victimizer. By leading citational dialogue (Oraic Tolic, 1990) with religious, mythological and folklore motives of lambs and falcons, this syntagm represents the semantic core of the travelogue.

A certain way to the development of trans-national identity thought is leaving the narrow ethnic, ethical, state, political, religious and especially closed intellectual circles. The reversal to The Other (Pageaux in Dukic, Blazevic, Plejic Poje, Brkovic 2009) and to the different enables the self-observation and exit from Plato's cave (Platon 2002) that opens the possibility of perceiving the wider cultural and social context of human society. In the binary opposition I-The other, the image of both members, even though imaginary, on which their identity codes are built, is manifested.

The image of the unknown Other, no matter how subjectively oriented, opens the way to knowing "the Other" and "the different": it also enables knowing different cultures, finding commonalities. It removes the border which is not as big as a man crafted in his own cave, not distinguishing the shadows on the trail of unknown light, believes it is.

Through citationally established links with other literary texts, phenomena from a wider cultural field and non-literary text, travel literature increasingly becomes a source of literary and cultural memory and testifies to a specific time that lives in a certain place.

The travelogue Black Lamb and Grey Falcon by Rebecca West is a text in which the author establishes citational dialogue with the history and culture of the countries she visited. Introducing the facts that are confirmed by official historical sources, the author often attributes the data from literary texts and folklore tradition to history that entered Yugoslav culture, through the second-rate modelling system. As such, they act more as parts of legends than parts of history. The realized dialogue is the basis on which the identity codes of a society, constructed in this work, are built. The travelogue is the discourse that uncovers "a part of the world, but at the same time, as it is about interference, the travelogue writer as its creator is being uncovered, too." (Duda 1998, 335) 


\section{MONTENEGRO IN THE TRAVELOGUE BLACK LAMB AND GRAY FALCON}

Rebecca West travelled to Yugoslavia three times in the period from 1936 to 1938. The result of those travels is the travelogue Black Lamb and Grey Falcon which was published for the first time in 1941. Professor Nikola Koljevic translated it in Serbo-Croatian language for the first time in 1989.

The travelogue Black Lamb and Gray Falcon is divided into 12 chapters (Prologue, Journey, Croatia, Dalmatia, Expedition, Herzegovina, Bosnia, Serbia, Macedonia, Old Serbia, Montenegro and Epilogue). Within each chapter, the travelogue subject does more than merely construct images of the places and people she visited. Particularly in the Montenegro chapter, the travelogue subject narrates about Montenegrin historical figures, and she produces a convincing image of The Other.

The chapter on Montenegro is structured in seven narrative units: Journey, Kolashin, Podgorica, Skadar Lake, Cetinje I, Cetinje II and Budva. The objective time of the travelogue story that involves the Montenegrin chronotope is interrupted by anachronies expressed through the subjective or objective type of analepses, depending on whether they are retrospective movements of the travel writer or of the focalizer.

Analepses (Genette 1980) often include a period of several centuries, and in the encircled narrative segment, the image of Montenegrin rulers, socio-cultural atmosphere of Montenegro and the Montenegrin national identity are modeled. Therefore, space becomes a construction of cultural memory.

During the three days spent in the above mentioned chronotopes in the collaboration of the travelogue subject and space, the image of society, its culture, history, geography, ethnography is modeled. The travel subject dominantly uses the ideological focus (Uspensky 1979) of the character of guide and companion, Constantine (Svetislav Vinavera, Serbian poet), and according to the information she gets from him, she forms and develops the image of Montenegrin national identity. Thus, the travelogue subject and focalizer belong to different cultures, and in the collaboration of different national identities, the recipient is given the opportunity to build 
a trans-national image and to leave the narrow national frame.

The travelogue subject, whose narrative level is primary, temporarily keeps her distance and gives word to characters-protagonists and focalizers that are expressed through non-narrative parts of the text (general claims, descriptions, and conversations between the narrative subject and focalizer), contributing to objectivity and reliability of the receiving content.

\subsection{Journey}

In the narrative unit Journey travelogue subject resides in chronotopes Pec (the microchronotope Pecka Partrijarsija), Andrijevica, Plav (Lake Plav) and Kolashin. She describes the nature of visited chronotopes and the mentality of people she meets. She also constructs, conditionally speaking, characteristics of Albanian, Montenegrin, Turkish and English mentality.

The travelogue subject, by describing beauties of Montenegrin relief through the line of images, degrades prejudices about Montenegro as a rocky and unfertile land:

There are as good as Swiss flowers. Where the road mounted to the pass it hair pinned across a slope too high for trees, which was clouded purple with crocuses, golden with kingcups. On the razor-edge of the pass we looked, as one may often do in Switzerland, backward and forward at two words. (...) It is not, as the school books have it, that Montenegro is barren - that is a delusion of those who see it only from the sea. Its inland half, if it has little for the plough, has many woods and pastures. But they are held in a cup of rock, they are insulated from the common tide of warmth that suffuses the rest of earth. What the cup holds is pure... (West 1946, 394)

In this narrative unit she also constructs imagological description of Lake Plav and Andrijevica:

A circle of water lay in a square of emerald marshland, fringed with whitish reeds, and framed by hills patterned with green grass and crimson earth, with sheer wall of snow mountains 
behind them. The glowing hills and the shining peaks were exactly mirrored in the lake, and received the embellishment of a heavenly bloom peculiar to its waters. (West 1946, 395)

(...) Andriyevitsa, a village of fifteen hundred inhabitants, which we came to after ten miles' drive through olive groves and plum orchards, is well set on a ledge above a river with heaths and pinewoods about it, and has a handsome main street planted with great trees and lined with substantial stone houses, which are ornamented with fine balconies, an architectural feature which marks that one has crossed the cultural watershed and has come down on the side of Dalmatia and Venice and the West, for the Oriental cares little for them. In spite of these advantages its effect on the stranger is cold and dreary. (West 1946, 396)

Besides the relief description, from the viewpoint of travelogue subject, the image of Montenegrins' physiognomy is constructed. They are described as ethnos of great physical beauty:

The beauty of both the men and the women is beyond what legend paints it, because legends desire to please, and this perfection demonstrates that there can be too much of a good thing. They are fabulous non-monsters. Such symmetry of feature and figure, such luster of hair and eye and skin and teeth, such unerring grace chokes the eye with cream. (West 1946, 396)

Further, taking the focus of character Constantine, the travelogue subject upgrades the identity image of Montenegrins:

They are nothing but heroes. If they eat or sleep it is so they shall wake up heroes. If they marry it is so that they should beget little heroes, who would not trouble to come out of their mothers' wombs if they are not certain that they would grow up in heroism. They are like the people of Homer as any race now living: they are brave, beautiful and vainglorious. (West 1946, 399)

A stereotype that became part of the cultural memory is that the Montenegrins are proud warriors and great heroes but they are lazy for kinds of work they are not attracted to. They tend to enjoy life performing 
functions in government or enjoy in undeserved, pensions:

So the Montenegrins are not really interested in any kind of work, and that makes it very difficult to fit them into the modern state of Yugoslavia.(...) So they poster the Government with demands for posts as functionaries and for pensions, which are of a terrible simplicity, for there is no need for so many functionaries, and if there were these people could not perform their functions, and God Himself, if He had a knife at His throat, could not invent a reason why they should all have pensions. This is hard for a poor country like Yugoslavia (...) because the Montenegrins are empty-headed except for their wild and unthinking heroism, which is to say they are often like madmen. I tell you this country is a sacrifice to itself of itself, and there is nothing left. (West 1946, 400)

There is a question whether these features belong only to Montenegrins. Dignity, pride and reputation are qualities that Montenegrins stubbornly nourish as a part of national being and they are one of the stereotypes that do not resist time. They are best described in two anecdotes through which the identity image has been developed:

(...) there was no end to the fairy-tales that the Montenegrins had to tell to themselves about themselves. (...) One is really true, it was a thing noticed in the Balkan wars. You know when soldiers drill they have to number off- one, two, one, two-. In the Montenegrin Army it could not be done. No man was willing to be second, so the first man said: 'One'-, and the second said: 'I-am-beside-him'. The other may be true, perhaps only in the spirit. It is said that a traveler asked a Montenegrin: 'How many of your people are there, 'and he answered: 'With Russia, one hundred and eighty millions,' and the traveller, knowing there were not two hundred thousand of them, said: 'Yes, but how many without the Russians' and the Montenegrin answered: 'We will never desert the Russians'. And it was not a joke, for the vainglory of these people was necessary to them or they would be conquered in battle. (West, 1946, 400)

Further, the travelogue subject creates an image of the Montenegrin chronotope through a binary opposition of beauty that leaves us breathless and cruelty that warns us. The travelogue subject puts the tragic image of 
a woman who survived her husband's death, imprisonment, loss of family and suffering, into the beautiful landscape. (West 1946)

Through the fate of a woman whose character is characterized by the strength with which she submits her life, and wisdom to try to understand it, the character of a proud Montenegrin woman is modelled. It also shows the cruelty of war as a universal evil, which is common not only for one state, nation or individual but is already a trans-national problem that has only one outcome: tragedy and absurdity of its existence.

In the chapter Journey the travelogue subject introduces the character of cab-driver and his friend constructing the identity of the Albanian people:

The cab-driver was a sombrely handsome young man of a type familiar in the Balkans, his friend was a natural comedian, a Robin Goodfellow, with straight red hair long about his shoulders, a crowing voice and stiff, signalling hands. They were Roman Catholics, but I found they knew nothing of the sayings or doings of Pope Pius X. (...) They were resentful against the Government and expressed the desire and even an intention to murder as many of its officials as possible (...) (West 1946, 388)

The French they could not abide. They had fought against them in the Great War, they said, and they were glad of it. They liked, they said, the Germans and the Bulgarians, and they hated the Serbs. (West 1946, 390)

Through the characters of a cab-driver and his friend the recipient constructs the image of Albanians as people of great physiognomy with tendency of selective hatred, a people who are not committed to their own faith and who bring judgment on an individual or society according to prejudices they formed in their sociocultural ambience.

Further, this ethnos is described from the travelogue subject's viewpoint:

We met an Albanian wearing a white turban with its ends brought across his throat, to hide one of the goitres which are so common in the mountains, and his wife, a raw-boned woman wearing a black dress which oddly broke into a flounce just above her knees, with something of a Cretan air. (...) Their leathery 
faces slowly split into enormous grins as they grasped our astonishment. All these people on the road were very deliberate and stiff and emphatic in their movements and their speeches, like frescoes come to life. One woman, who was sitting in a cart with her young child under her blue mantle, resembled exactly one of the Madonnas of Dechani, twisted by the strain put upon her endurance by her love. Again it seemed that Byzantine art is not so much stylized as we believe, and that it may be a more or less naturalist representation of a highly stylized life. (West $1946,393)$

Through the image of the appearance and behaviour of a group of Albanians, the opinion that they are conceited, measured and that they possess "Hercules" abilities is made.

Through Constantine's viewpoint, in the segment which includes the event from the time of Balkan war when in 1912., Montenegro captured the village near Plav from the Turks, the character of Muslim priest who joined the Orthodox Church and was appointed a major in the Montenegrin army is modelled:

His first action when left unsupervised was to hold a courtmartial on his former congregation and to shoot all those who refused to be baptized. (West 1946, 395)

The selected image is not only representative of the Turkish ethnos, it also testifies to human nature in general and its tendency towards puritanism or self-sustainment.

In this chapter the travelogue subject leads the citational dialogue with history and introduces figures Bishop Danilo Petrovic, Prince Danilo and Ivan Crnojevic linking events that are partly in accordance with history, to their identities.

\subsection{Kolashin}

In the chapter Kolashin, the image of Montenegrin national identity is being updated through the modeling of a Montenegrin woman, from the travelogue subject's viewpoint. 
She was one of those widows whose majesty makes their husbands dead in a particular way. Her large Elgin Marble head bore a crown of lustrous black plaits, and was veiled by a black lace mantilla: her full black gown draped a massive and dignified body which it was impossible to imagine as divided into limbs in the usual manner. (West 1946, 405)

The Montenegrin female characters reflect Montenegrin patriarchal ethic where the woman is hardworking, dignified, a loyal wife (even after her husband's death), the mother of a hero ready to fight with all the cruelties of life, but always in service of a man even after his death. Contemporary society degrades this stereotype.

Besides the moral characteristics of Montenegrins the travelogue subject also draws attention to their language (in those times it was called the Serbo-Croatian language, and she notices that 'it can easily be converted to verses'), traditional food and wine by which Montenegro is still known for.

But I ate a great deal, for the stately landlady brought us reach bean soup, and some home-cured raw ham, and a dish of lamb roasted with herbs, and a pile of little cakes, made in the Turkish fashion, of pounded fruit and nuts pressed between two layers of pastry, very well made indeed. There was also some good wine from the southern slope of Montenegro. (West 1946, 412)

\subsection{Podgorica}

In the chapter Podgorica the Montenegrin relief from Kolashin to Podgorica has been described. The travelogue subject emphasizes the image of unusual rocky landscape of this part of the Montenegrin chronotope, the beauty of Moraca River and she gives a brief overview of architecture in Podgorica:

Then we crossed a pass into the traditional Montenegro, the land which defies cultivation so that no peasantry could live there where its breast not bound with oak and triple bronze (...) There one sees often enough trees growing askew from interstices of 
a hillside paved with rocky slabs: but here it is as if a volcanic eruption had been arrested just at the moment when it was about to send the whole countryside flying into the air (...) As we came down towards the lowlands and the distant sea we run within sight of a canyon, cut by a river that flowed a dull bright-green, clear and yet snake-like, over sand and pebbles. This colour delights the Yugoslavs very much. (West 1946, 414-415)

We had not wasted one moment looking at the sights of Podgoritsa, for too evidently it has none. There are hardly any relics of the Turkish occupation and as modern town it lacks charm. It is solid for it used to be the second town of Montenegro, and it is now the administrative capital of the district, but it is built without eloquence. (West 1946, 416)

In the chronotope of one of the Podgorica's hotels, from Constantin's viewpoint the image of political situation in Albania before The Second World War and its relations with Italy has been constructed. The image will be completed in the chapter Budva with the image of Albanian people suffering:

(...) It is certain that there is trouble to come in Albania, that the Italians are to do something frightful to the Albanians, and that their friends the Germans, who do not so greatly love them, wait outside to see how it goes. I do not think you English know anything about Albania. For it is nearly Italian, they have their officials there, they control the whole country; some day they will have their army there too, and it will be as a pistol pointed at Yugoslavia'. He spoke as a Serb, as a Jew, as an inheritor of the French tradition. (West 1946, 420)

The image of political situations, of interstate relations and fragmentary observations of Italians, Germans and English has been constructed. Besides that, Constantine's character which becomes the bearer of the cultural and political identity of the Serbian people has also been constructed. 


\subsection{Skadar Lake}

In the chapter Skadar Lake, the travelogue subject gives altered image of the Montenegrin relief in contrast to the previous one. In this image the plains planted with corn, tobacco, apples, fig-trees, mulberry trees, and the amazing beauty of Skadar Lake and Vranjina, dominate.

In accordance with the image of nature, the images of Montenegrin women and children characters are being modelled:

On this side of Montenegro the women have lost their Byzantine tensity and are more like Du Maurier duchesses, with the same numismatic profiles and uptilted, humorless dignity, and the same underlying simplicity and amiability and resolutions in good behaviour" (...) 'There is a child looking at us from behind those boulders', said my husband. 'Say nothing and she may come nearer,' said Constantine, But we must be very cautious, here even the little ones are shy and proud. (West 1946, 422)

Leaving national frames and opening to the different, unknown, in contact of two different cultures, is obvious in narrative fragment where the meeting of travelogue subject and Montenegrin girl in the chronotope Skadar Lake is described.

When she had the nosegay she thought correct, she brought it to me at a leisured pace, curtseyed and kissed my hand. For a minute I could not bear to let her go: I put my arm round her shoulders, for to have this exquisite creature of remote and superior race so close was such luck as having a butterfly alights on one's fingers. She bore my touch with good manners (...) (West 1946, 425)

The love and feeling of closeness for someone for whom, according to prejudices, we should not feel anything, are the brightest example of breaking stereotypes, and therefore breaking of all interpersonal barriers. 


\subsection{Cetinje I}

In the chapter Cetinje the travelogue subject resides in the Rijeka Crnojevica and Cetinje chronotopes. She draws attention to the beauty of Rijeka Crnojevica, especially the beauty of Obod Monastery (the oldest South Slavic and one of the oldest Slavic printing houses was founded in Obod Monastery in the $15^{\text {th }}$ century) and she constructs the image of Cetinje:

It lies in a stony crater like a town set inside the brainpan of an enormous skull. Its square stone houses, laid out in broad streets, are typically Montenegrin in a Puritanism that suffers no decoration save an occasional great tree. (West 1946, 429)

The Montenegrin female characters are the centre of attention of the travelogue subject in this chapter, too:

We were to notice then and later that the female Montenegrin is better to look at as a little girl or as an ageing woman than in the period of her sexual attractiveness, for then she presents a disconcerting blankness. Her face is like a niche designed for a statue it does not hold. Perhaps this is because there is part of a mature woman's nature which must be filled by sexual love or a sublimation of it, or is sensibly empty, and the male Montenegrin has kept his liberty only by maintaining a continuous masculinist frenzy which prevents him from loving women or letting them forget lack of love in thought and work. This leaves the female Montenegrin no worse than many women in the industrialized West whose men are bled white by invisible enemies more dangerous than the Turks, but her tragedy is made more dramatic by her marked physical appropriateness to love. (West 1946, 426-427)

This segment is manifold modulated. The characters of Montenegrin woman who is born for love and Montenegrin man who is subordinated to patriotism which brings many prohibitions like binding the right for instinct and emotions for they are not worthy of higher goals, are modelled here. The characters of people from industrialized West whose emotions are destroyed by exhausting industrialization of society are also modelled in this segment. 
In this chapter, the travelogue subject draws attention to Montenegrin folklore, costumes and weapons as fashion detail. She also introduces the characters of Bishop Sava, Bishop Vasilije and Scepan Mali and she interprets their relationship with Russia by developing them through fragments of individual episodes that happened (did not happen) in political life of these historical figures.

From the dialogue with Sava, Constantine's friend, a semantically emphasized image stands out, testifying to gender inequality as the identity feature of the Montenegrin nation:

Later when he heard that I had received the Order of St. Sava for lecturing in Yugoslavia, he said to my husband: 'And you, did you not get anything! Here in Montenegro we men would not be content if our wives were given something and we did not have it too.' A man should have everything, because he is a hero, because he is half divine in his courage, and because there must be predestined attraction between him and the fruits of the earth if his lot is not to be intolerably uncertain. The theory would be invalidated if women were allowed to draw to themselves a single fruit, for though women may be heroic it is only as amateurs, there are never dedicated, full-time professionals. (West 1946, 433)

Gender inequality crosses the boundaries of the Montenegrin nation, and as such it is trans-national feature that weakens with the progress of human society.

\subsection{Cetinje II}

While staying in chronotope Cetinje the travelogue subject pays attention to buildings of culture: Billiard (Petar II Petrovic Njegosh), Cetinje Monastery, King Nikola's Palace and State Museum of Montenegro.

The narrative content of this segment is the historical data about the Montenegrin rulers (Petar II Petrovic Njegos, King Nikola and his daughters, Prince Danilo) that are often not in agreement with history and grow into a legend. However, they make persuasive imagery of Montenegrin figures and the events that belong to the $19^{\text {th }}$ century.

In the chronotope State Museum, a semantically important motive 
of transience and deterioration of the once powerful Turkish civilization, constructed from Sava's viewpoint, is modelled. The Turks are shown through the binary opposition - I in the past and I now. On one hand there is curator of the museum, a devote Muslim who obeys all prohibitions, lives in the spirit of tradition, wears a fez and glorifies the past; on the other hand, there are Turks adapted to new historical circumstances:

He took them to see the collection, and began to show them the plaster cast of the Pasha's head, as something that should make them feel very sorry, because the poor man had been a good servant to the Sultan and to Mohammed, and the Montenegrins cut off his head and brought it here, and took his mask of it so that they might gloat over it. But the Turkish journalists would hear nothing of that: they said: 'We will rather not think of such things. He was one of our soldiers and his head was cut off. But it was we who brought into Europe the sort of civilization that cuts off heads, and Ataturk has taught us not to be proud of it'. (West 1946, 452)

Through this image the Montenegrins and Turks identities are modelled. Their identities are not static; they tend to change. The fact that the Muslim curator was entrusted with the State museum (a chronotope that represents heterotopia that contains Montenegrin identity), and the attitude of the contemporary Turks about tradition moves the borders between Turkish and Montenegrin nation. It also testifies to relativity of stereotypes. This leaves a space where only the future liberated from the burden of the past is the one which could be good.

The motive of deterioration of Turkish civilization reflects in the travelogue subject's fear of deterioration of English civilization and the motive of fight to avoid it. Thus the travelogue subject models the image of the English national identity:

My civilization must not die. It need not die. My national faith is valid, as the Ottoman faith was not. I know that the English are as unhealthy as lepers compared with perfect health. They do not give themselves up to feeling or to work as they should, they lack readiness to sacrifice their individual rights for the sake of the corporate good; they do not bid the right welcome to the other man's soul. But they are on the side of life, they love justice, 
they hate violence and they respect the truth. (...) This measure of wisdom makes it right that my civilization should not perish. (West 1946, 453)

(...) If I wanted my civilization to survive under attack-and I would have learned from this journey that it was going to be attacked, even had I started in ignorance-I had to be willing to fight for it. This necessity did not lessen because fighting meant the sacrifice of most of the subtle variations that it has been the happy business of the intellect to impose on the instinctive life. I had to be willing to fight for it even though my own cause could not fail to be repulsive to me, since the essence of civilization was disinclination for violence, and when I defended it habit would make me fear that I was betraying it. (West 1946, 454)

The motive of relativity of someone's power duration is also structured in the image of deterioration of Petrovic dynasty which is upgraded with the image of a warehouse with deferred items that belonged to family Petrovic:

For immediately we entered the palace we were reminded of the dissolution of yet a third empire, not by a stench, a ghostly echo of idiocy but by a fragrance. It happens that the system of provinces of banovinas which King Alexander devised put Tsetinye under the central control of Sarajevo, where the Moslem political party has great influence. (West 1946, 448)

Over there is a coach-house which I would like you to notice. For years it was crammed with trunks containing valuable articles of clothing and jewellery, the personal property of Nicholas and his family, who left them behind in the haste of their flight to Scutari. Poor as our people are, and accustomed to looting as an actual part of military technique, nobody touched these things. They thought it beneath their dignity to take what had belonged to their unworthy king. (West 1946, 453-454)

In a previously constructed image a trans-identity motive, changed attitude of the people towards the former representatives of the government, and identity peculiarities of Montenegrins are also noticed. They distance themselves from everything they consider to be not moral enough and deviating their understanding of heroism. 


\subsection{Budva}

In the chapter Budva, the travelogue subject along with her followers, resides in chronotopes Lovcen and Budva. From Sava's viewpoint, Lovcen is perceived as a mountain with the most beautiful view in Yugoslavia. The combination of diversity is also manifested in this chronotope. The meeting of unquenchable beauty of the mountain with the relaxing beauty of the sea is the frame in which the travelogue subject places a contrasting image of Montenegrin: a giant with both a gentle heart and a cruel face. (West 1946)

In the chronotope Budva from Sava's viewpoint, the image of the English mentality is being modelled. It is modelled through the image of King Edward who is described as modest and unobtrusive. "I found him most sympathetic. I have never had to look after any ruler, or indeed any public character, that was so anxious to be considerate." (West 1946, 461)

The identity of English nation is largely manifested in the travelogue subject's behaviour and thinking. This ethnos is open to others and different, they are tolerant, objective in describing others, and they are ready for self-criticism.

Besides describing the beauties of Budva and the travelogue subject's and his fellows' enjoying in swimming, in this chapter the motive of the upcoming war appears and it is presented through Italian aggression in Albania. The chapter that refers to Montenegro finishes with this motive:

It is a massacre. The officials all are bought by Italian money, and they have taken the four hundred young men who were most likely to give Italy trouble when she takes the country, and they have pretended it is a Communist rising, and they have killed them all. It is all nasty, so nasty, and it will not stop till the end." (West 1946, 463)

So, the travelogue subject burdens the frame of this chapter with the image of upcoming evil and with the announcement of The Second World War that started at the time when the work Black Lamb and Grey Falcon was created. 


\section{CONCLUSION}

By constructing the image of Montenegro, the author draws attention to features of Albanian, Turkish, English and Serbian ethnos, but also to the trans-national features of any other nation, because there is no distinction assigned to one nation that would not be recognized in the other. The Montenegrin chronotope is distinguished by the richness of diversity. In a small area one can see the mountains with untouched nature, fertile plains around the lakes and rivers, the beauty of the sea, rich history born from legends, and legends born from history. The Montenegrin ethnos is in harmony with its chronotope and, because of a long battle with The Other for its preservation it looks like it merged with itself.

The image of the Other about the Other (even if it is often constructed on the basis of a single situation or a single event, and therefore cannot be considered as representative) received in the travelogue Black Lamb and Grey Falcon contributes to knowledge about European nations and it also contributes to imagology as a part of comparative literature.

The travelogue of Rebecca West was originated from the time of blooming English travelogue literature. By citational dialogues with history and intertextual elements that are interwoven through the text, this work contains the elements of postmodernism. The introducing of motives from history, geography, ethnography, literature of visited countries and countries that travelogue subject travelled through, places this travelogue into a special type of heterotopia. (Fuko 2005) Travelogue literature through this work certainly gets a deserved place in the field of literature and culture.

The key transnational motive in the title of this work is the motive of black lamb and grey falcon; the motive that warns and drives a man to wonder why he sacrifices or is sacrificed. In this binary opposition there is the symbol of a black lamb a victim, on one hand: on the other hand there is imagery of a falcon, a symbol of strength, beauty, rising, superiority and victory. (Chevalier, and Gheerbrant 1987) Even if those two motives are confronted, they simultaneously last as part of human life where a man is sometimes a victim and sometimes a victimizer. 


\section{REFERENCES}

Bahtin, M. 1989. O romanu. Translated by Badnjarevic, A. Beograd: Nolit. Bal, M. 2002. Naratologija. Translated by Rastislava, M. Beograd: Narodna knjiga.

Chavalijer, J., and Gheerbrant, A. 1987. Rječnik simbola. Zagreb: Nakladni zavod Matice hrvatske.

Duda, D. 1998. Priča i putovanje. Hrvatski romantičarski putopis kao pripovjedni žanr. Zagreb: Matica hrvatska.

Dukic, D., Blazevic, Z., Plejic Poje, L., and Brkovic, I. 2009. Kako vidimo strane zemlje, Uvod u imagologiju. Zagreb: Srednja Evropa.

Fuko, M.,2005. Hrestomatija. Translated by Milenković P., Novi Sad:Vojvođanska sociološka asocijacija.

Genette, G. 1980. Narrative Discourse Revisited. Ithaca: Cornell Universsity Press.

Lotman, Y. 1976. Stuktura umjetničkog teksta.Translated by Petkovic,N. Beograd: Nolit.

Marčetić, A. 2003. Figure pripovedanja. Beograd: Narodna Knjiga/Alfa.

Pageaux, D.-H. 'Od kulturnog imaginarija do imaginarnog' In Kako vidimo strane zemlje, Uvod u imagologiju. 129-156. Zagreb: Srednja Evropa.

Platon. 2002. Država. Translated by Vilhar A. and B. Pavlovic. Beograd: BIGZ.

Toljic Oraic, D.1990. Teorija citatnosti. Zagreb: Grafički zavod Hrvatske.

West, R. 1946. Black Lamb and Grey Falcon. London: MACMILLAN\&COLTD. 
